\title{
Waris Pengganti \\ sebagai Penyelesaian Waris Islam di Indonesia
}

\author{
Abdul Jamil
}

\begin{abstract}
Substitute here as orderred in Islam Law compilation as an elaboration from Al-Qur'an verses interprefation on more extensive Islam heir matter. This is also as an resolution for legal controversy in islamic heir principle as part of Islam heir Law in Indonesia.
\end{abstract}

\section{Pendahuluan}

Persoalan waris mewaris adalah persoalan yang pasti terjadi dan akan dialami manusia, sehingga hukum waris sebagai sarana bagi penyelesaian waris selalu menarik, meskipun ada kesan cenderung doktriner dan tidak berkembang. Pendapat ini di satu sisi dapat dibenarkan, apabila dilihat ketentuan bagianbagiannya yang pasti sebagaimana diatur dalam sumbernya yaitu al-Quran dan al-Hadits. Akan tetapi di sisi lain, menjadi tidak benar manakala dilihat dari hal-hal yang tidak diatur dalam sumber hukum utama (al-Quran dan al-Hadits) dan itu memerlukan penafsiran karena ada ketentuan yang memerlukan ijtihad manusia. Dalam hal ini, sumber hukum ketiga yaitu ijtihad sangat berperan. Sementara penafsiran melalui ijtihad ini dapat dipengaruhi oleh banyak faktor, baik faktor intern atau ekstern diri orang yang mengambil ijtihad, misalnya adat istiadat dan struktur sosial masyarakat.

Rumusan-rumusan hukum secara umum apabila dicermati sebagian besar materinya mencerminkan masyarakat. Akan tetapi berbeda dengan hukum waris yang substansinya mencerminkan sistem kekeluargaan di dalam masyarakat yang didasarkan atas sistem keturunan.'

'Abdullah Sidik, Hukum Waris Islam dan Perkembangannya di Seluruh Dunia Islam (Jakarta: Wijaya, 1984), hlm. 1.

${ }^{2}$ Hazairin, Hukum Kewarisan Bilateral Menurut al-Quran dan Hadits (Jakarta: Tintamas, 1982), hlm. 13. Baca Mohammad Daud Ali dan Habibah Daud, Lembaga-Lembaga Islam di Indonesia (Jakarta: Raja Grafindo Persada, 1995), hlm. 102. Baca juga Idris Djakfar dan Taufik Yahya, Kompilasi Hukum Kewarisan Islam (Jakarta: Pustaka Jaya, 1995), hlm. 29. 
Dalam sistem kekerabatan atau keturunan ada 3 (tiga) kelompok besar yang dapat mempengaruhi struktur masyarakat, yaitu Patrilinial, Matrilinial dan Bilateral (Parental). Ketiga sistem ini sebagian besar mempengaruhi hukum waris. Dalam hukum kewarisan Islam pada dasarnya sistem yang dianut adalah bilateral (parental) ${ }^{2}$ yaitu sistem kewarisan yang bersumber dari laki-laki dan perempuan. Ketentuan ini diatur dalam al-Quran surat anNisa ayat (7). Dalam ketentuan ayat ini dikandung pengertian bahwa antara laki-laki dan perempuan mempunyai hak yang sama untuk mewarisi harta yang ditinggalkan dari kedua orangtuanya dan kerabat-kerabatnya. ${ }^{3}$

Sebagaimana diketahui dalam hukum waris Islam ada dua pendapat besar yang dianut oleh masyarakat dalam menyelesaikan masalah pembagian waris. Dua sistem itu adalah Ahlussunnah dan Syi'ah. Keduanya mempunyai perbedaan prinsip walaupun berlandaskan pada sumber nash yang sama: al-Quran dan Sunnah Rasul. Perbedaan tersebut dilatarbelakangi oleh alasan politis, cara berfikir menafsirkan al-Quran dan Sunnah Rasul dan pengaruh adat setempat. ${ }^{4}$ Perbedaan prinsip ini berkaitan dalam menarik garis keturunan. Paham Ahlussunnah garis keturunan ditarik dari keturunan laki-laki (patrilinial) dengan demikian keturunan perempuan dari garis perempuan dipandang mempunyai kedudukan yang lemah, sehingga dapat ditutup oleh ahli waris dari garis lakilaki, sedangkan paham Syi'ah mendudukkan keturunan perempuan dan laki-laki mempunyai kedudukan yang sederajat.

Dari dua pendapat di atas, pendapat yang pertama yaitu Ahlussunnah yang dipakai oleh sebagian besar umat Islam dalam menyelesaikan pembagian warisan. Apabila dikaitkan dengan surat an-Nisa ayat (7), maka sistem yang digunakan oleh Ahlussunnah dipandang tidak adil, oleh karenanya dibutuhkan suatu ijtihad untuk menyelesaikan kedudukan keturunan perempuan dari garis perempuan.

Hukum kewarisan Islam di Indonesia termasuk menganut paham Ahlussunnah yang bermadzhab pada Syafi'i. ${ }^{5}$ Dalam menyelesaikan permasalahan kewarisan yang menyangkut keturunan perempuan dari garis perempuan hubungan kekerabatannya lemah dibanding laki-laki, oleh sebab itu keturunan perempuan dari perempuan ditutup oleh keturunan lakilaki. Penyelesaian inipun dianggap tidak adil dan perlu dilakukan rekonstruksi ijtihad terhadap hukum kewarisan Islam di Indonesia.

Rekonstruksi ijtihad dalam hukum kewarisan Islam berkaitan dengan keturunan perempuan dari garis perempuan di Indonesia diambil suatu hasil ijtihad dengan menggunakan istilah waris pengganti, yang pengertiannya tidak sama dengan waris pengganti dalam hukum waris Barat dan adat, karena bagiannya dibatasi maksimal tidak boleh melebihi bagian yang digantikan kedudukannya. Hasil ijtihad ini dipandang menyelesaikan masalah sesuai dengan

3Sayuti Thalib, Hukum Waris /slam di Indonesia. (Jakarta: Bina Aksara, 1987), hlm. 6.

${ }^{4}$ Abdullah Siddik, op. cit, him. 23.

slbid, hlm. 29.

"Akhmad Minhaji, "Tradisi jitihad dalam Islam (Dulu, Kini,dan Masa Mendatang)," Jumal Hukum No. 17 Vol. 8 (2000), hlm 14 . 
ketentuan al-Quran. Kemudian hasil ijtihad tersebut dikodifikasikan dalam kitab hukum yang disebut dengan istilah Kompilasi Hukum Islam (KHI) yang terdiri dari tiga buku, yang pemberlakuannya berdasarkan Instruksi Persiden RI No. 1 Tahun 1991.

\section{Adat dalam Hukum Waris Islam}

Membahas Hukum Kewarisan Islam di Indonesia sama dengan hukum-hukum Islam lainnya, yang tidak dapat dilepaskan dari pendapat para ahli hukum Islam yaitu Maliki, Hambali, Syafii dan Hanafi. Keempat madzhab ini kemudian dikenal dengan sebutan paham Ahlussunnah.

Konstruksi pemikiran keempat madzhab ini sangat berpengaruh terhadap pemikiran para tokoh ahli hukum Islam setelahnya termasuk di Indonesia dalam mensikapi perkembangan hukum Islam. Sebab, pola dalam proses ijthad selama ini cenderung logic of repeatation (pemikiran yang hanya mengulang-ulang yang sudah ada) dan logic of justification (karya-karya yang hanya menjustifikasi yang telah ada) dan hampirhampir tidak didukung oleh logic of discovery (logika yang mendorong lahimya penemuanpenemuan baru). ${ }^{6}$ Sementara dalam Islam pola atau metode seperti itu tidak dilarang atau dipandang sah, karena untuk menemukan hukum dengan cara ijtihad dianjurkan dan ijthad itu sendiri merupakan sumber hukum ketiga selain al-Quran dan as-Sunah (alHadits) dan merupakan suatu keharusan (necessity), kebutuhan (need), bahkan menjadi "lebih penting dan lebih sentral" dari al-Quran maupun al-Hadits dalam proses penemuan hukum.' Proses ijtihad ini tentu saja dengan syarat apabila dalam sumber hukum utama, al-Quran dan al-Hadits tidak menyebutkan atau tidak mengatur, maka manusia diberi kebebasan untuk menemukan hukumnya sendiri dengan batasan tidak boleh bertentangan dengan hukum utamanya, atau dengan kata lain bahwa hasil ijtihad itu tidak boleh menghalalkan yang diharamkan agama dan mengharamkan yang dihalalkan agama. ${ }^{8}$

Hasil penemuan hukum dengan jalan ijtihad dapat menghasilkan fiqh atau dapat juga Syiasyah Syar'iyah. Yang perlu dipahami dari hasil ijithad adalah produk hukum yang mempunyai sifat terbuka, yaitu mempunyai sifat berkembang dan menerima perbedaan. ${ }^{9}$ Sebab, ijtihad selain merupakan penemuan terhadap kasus-kasus tertentu (khusus) juga dipengaruhi oleh faktor-faktor subjektif dan objektif. Yang dimaksud faktor subjektif adalah hal-hal yang dimiliki oleh orang yang berijtihad itu sendiri, misalnya kedalaman ilmu orang yang berijtihad, sedangkan yang dimaksud objektif adalah lingkungan, perkembangan zaman atau adat istiadat, bahkah menurut Akhmad Minhaji tidak jarang terjadi sebuah keputusan hukum dipenganuhi oleh kepentingan individu atau kelompok masing-masing. Oleh karena itu, satu hukum tentang satu kasus tertentu dapat berbeda bukan karena berbeda teks yang digunakan tetapi karena perbedaan kepentingan masing-masing. ${ }^{10}$

7lbid, hlm. 9.

'Ahmad Sukardja, Piagam Madinah dan Undang-Undang Dasar 1945: Kajian Perbandingan tentang Dasar Hidup Bersama dalam Masyarakat yang Majemuk (Jakarta: UI Press, 1995), hlm. 13.

${ }^{9} \mathrm{lbid}, \mathrm{hlm} .10$.

${ }^{10}$ Akhmad Minhaji, op. cit,.hlm. 5-16. 
Berkaitan dengan persoalan hukum kewarisan, produk hukum yang dihasilkan masih didominasi oleh faktor adat. Pengambilan hukum adat sebagai.bahan berijtihad dalam Islam dibenarkan, yang dikenal dengan metode ijtihad istishlahi, yang mengambil adat sebagai hukum al-'adah atmuhakkamah."

Pengaruh adat (hukum adat) sebagai bahan ijtihad unfuk merumuskan hukum kewarisan Islam dapat dimengerti karena persoalan waris mewaris mempunyai hubungan yang erat dengan kekerabatan atau hukum kekeluargaan yang dianut seseorang. Hukum kekeluargaan dalam kelompok masyarakat yang satu dengan kelompok masyarakat lainnya tidak selalu sama. Hal ini umumnya dapat diketahui dari struktur sosial masyarakat yang plural. ${ }^{12}$ Persoalan hukum waris Islam yang berkembang sampai sekarang ini jika ditelusuri lebih jauh (historis) masih mempunyai kaitan erat dengan adat istiadat di mana sumber hukum islam merupakan hukum pertama kali berkembang (suku Arab). Hal ini senada dengan pendapat Asaf AA. Fyzee yang dikutip oleh Abdulah Siddik bahwa limu Faraidh yang telah berkembang sampai dewasa ini terdiri dari dua unsur, yaitu: ${ }^{13}$
1. Hukum adat dan kebiasaan yang berlaku di kalangan suku Arab. sebelum Islam yang tidak diubah dengan tegas oleh mereka sesuai dengan peraturan-peraturan yang ditetapkan di dalam al-Quran.

2. Peraturan-peraturan di dalam alQur'an yang membawa perubahan yang tegas kepada adat masyarakat Arab zaman Jahiliyah.

Pendapat di atas, apabila dikaitkan dengan asbabul nuzul ayat-ayat kewarisan mendekati kebenaran, misalnya dalam surat an-Nisa ayat (11) ini turun berkaitan dengan aduan istri Sa'ad bin Ar-Rabi' persoalan warisan Sa'ad bin Ar-Rabi' di mana seluruh harta peninggalan almarhum Sa'ad tanpa memberikan hak kepada istrinya dan 2 anak perempuan Sa'ad. Kemudian Rasulullah bersabda, "Semoga Allah segera memutuskan perkara ini." Kemudian turunlah ayat tentang waris ini. Selanjutnya Rasulullah memutuskan dan memerintahkan kepada paman dari anak almarhum Sa'ad bin Ar-Rabi' agar memberikan dua pertiga harta peninggalan Sa'ad kepada 2 orang putrinya dan ibu anak putrinya (istri Sa'ad) mendapatkan seperdelapan, dan sisanya

"Ahmad Azhar Basyir, Refleksi Atas Persoalan Ke-Islaman, Seputar Filsafat, Hukum, Politik dan Ekonomi (Bandung: Mizan, 1994), hlm. 133.

${ }_{12}$ Salah satu cara untuk melihat hukum kekeluargaan dalam kelompok masyarakat adalah dengan memperhatikan susunan kelompok masyarakat tersebut berdasarkan ikatan genealogis. Berdasarkan ikatan genealogis, susunan masyarakat pada dasamya terbagi ke dalam 4 (empat) kelompok, yaitu: Patrilineal, matrilineal, parental,dan altemerend. Lihat Otje Salman, Kesadaran Hukum Masyarakat temadap Hukum Waris (Bandung: Alumni, 1993), hlm. 48.

13Baca Abdullah Siddik, op cit, hlm. 4. 
menjadi bagian saudara kandung Sa'ad (paman dari 2 anak perempuan Sa'ad). ${ }^{14}$

Putusan Rasulullah sebagaimana riwayat di atas yang memberikan sisa kepada saudara laki-laki kandung Sa'ad apabila dikaji ada 2 (dua) alasan: yaitu (1) al-Quran tidak memberikan bagian khusus laki-laki kecuali suami atau ayah; (2) karena adat pada suku Arab menetapkan laki-laki mengambil (mewarisi) seluruh harta. Hal ini oleh Rasulullah tidak dirubah kecuali yang tegastegas oleh al-Quiran dirubah. Oleh karenanya Rasulullah memberi bagian saudara laki-laki sisa harta dari bagian istri dan anak perempuan.

Ketetapan hukum kewarisan yang diambil .oleh Rasulullah dalam menyelesaikan kasus warisan almarhum Sa'ad bin Ar-Rabi' ini tidak merubah secara mutlak kebiasaan (adat) suku Arab bahwa laki-laki memiliki posisi yang kuat dalam hal waris mewaris, melainkan mempunyai kedudukan yang sama dengan perempuan. Hal ini terbukti di mana Rasulullah menetapkan laki-laki diberi bagian setelah dikurangi bagian anak perempuan dan istri.

Penyelesaian yang diambil oleh Rasulullah atas kasus istri Sa'ad dengan saudara lakilaki kandung Sa'ad tersebut atas dasar surat an-Nisa ayat (11, 12 dan 176) kemudian diambil suatu pemahaman oleh para ahli hukum Islam yang terkenal dengan paham Ahlussunnah dengan membagi menjadi 3 (tiga) golongan ahli waris yaitu, (1) dzawil funudl, (2) 'ashabah dan (3) dzawil amam.
Ahli waris yang dimaksud dengan dzawil furudl ialah mereka yang mempunyai bagianbagian tertentu sebagaimana disebutkan dalam al-Qur'an atau as-Sunah. Bagianbagian tertentu yang disebut dalam al-Quran adalah bagian $1 / 2,2 / 3,1 / 4,1 / 6,1 / 3,1 / 8$. Sedangkan 'ashabah adalah ahli waris yang tidak mendapatkan bagian tertentu dan baginya menerima sisa setelah diambil (dikurangi) bagian dzawil furudl, sehingga dimungkinkan menerima seluruh harta warisan apabila tidak ada dzawil furudl, atau menerima sisa yang banyak apabila bagain dzawil furud/sedikit dan juga bisa kemungkinan tidak menerima apabila harta warisan itu habis dibagi dzawil furudl. Sedang yang dimaksud dengan dzawil arham adalah mereka yang mempunyai hubungan keluarga dengan pewaris tetapi tidak termasuk golongan waris dzawil furudl dan 'ashabah yaitu terdiri dari laki-laki dan perempuan dari garis perempuan. ${ }^{15}$

Sekarang yang menjadi persoalan adalah apakah hukum adat sebagai dasar untuk menyelesaikan waris mewaris masih dapat dipertahankan. Dua pendapat besar dalam hukum waris Islam yaitu Ahlussunnah dan Syiah sama-sama membenarkan; tetapi ada perbedaan dalam sikap. Misalnya Áhlusunnah membenarkan dasar-dasar hukum adat Arab tetap berlaku, kecuali yang secara tegas menyimpang dari al-Quran, sedang golongan Syiah menganggap bahwa antara laki-laki dan perempuan mempunyai hak yang sama untuk saling mewarisi. Penafsiran Syiah ini lebih luas

\footnotetext{
${ }^{14}$ Baca Muhammad Afi Ash-Shabuni alih bahasa A. M. Basalamah, Pembagian Waris Menurut Islam (Jakarta: Gema Insani Press, 1995), him. 24.

${ }^{15}$ Baca Ahmad Azhar Basyir, Hukum Waris Islam (Yogyakarta: FE Ull, 1990), him. 24-27.
} 
menafsirkan adat kebiasaan sepanjang tidak bertentangan dengan al-Quran dan asSunnah, sehingga golongan Syiah hanya membagi 2 golongan waris: $d z u$ fara'id dan dzu qarabat. ${ }^{16}$

Pendapat Syiah apabila disandarkan pada kaidah fiqh yaitu adat kebiasaan dapat dikukuhkan sebagai hukum yang sah (al'adah al-muhakhamah), ${ }^{17}$ tentu saja dengan syarat adat yang tidak bertentangan dengan Islam. Dalam bahasa yang lain adalah hukum adat baru berlaku kalau tidak bertentangan dengan Islam, ${ }^{18}$ maka sah-sah saja sebagai hukum yang dapat dipedomani. Sebab dalam hukum kewarisan Islam sebagaimana ditentukan dalam surat an-Nisa ayat (7) antara laki-laki dan perempuan didudukkan dalam suatu derajat yang sama untuk dapat menjadi ahli waris dari kedua orang tunya dan kerabatkerabatnya, yang dibedakan dalam hal perolehan bagiannya sebagaimana dijelaskan dalam an-Nisa ayat $(11 ; 12$ dan 176), yaitu ada perbedaan antara laki-laki dan perempuan yaitu 1: 2 (satu banding dua).

Sistem Hukum Waris Islam di Indonesia dalam Praktik

Hukum waris di Indonesia sebagaimana diketahui ada 3 sistem hukum yang berlaku: Barat, Adat dan Islam.
Sebagaimana diuraikan di alenia sebelumnya bahwa hukum kewarisan Islam yang berlaku di kalangan masyarakat indonesia masih terpengaruh oleh 4 (empat) madzhab besar, yaitu Ahlussunnah yang menggolongkan 3 golongan ahli waris, yaitu dzawil furudl, ashabah dan dzawil arham. Penggolongan yang dipergunakan oleh Ahlussunnah tidak bertentangan dengan sebagian sistem yang dianut dalam hukum adat di Indonesia, oleh karenanya sistem tersebut tidak ditolak oleh sebagian besar masyarakat lslam di Indonesia. Bahkan banyak masyarakat yang mempertahankan berlakunya paham Ahlussunnah untuk menyelesaikan masalah waris mewaris.

Paham Ahlussunnah dalam persoalan waris banyak dipengaruhi sistem kekeluargaan patrilinial - yang mengembangkan adat Arabsementara untuk konteks saat ini dipandang belum adil dalam menyelesaikan bagian keturunan perempuan dari garis perempuan. Pengaruh adat Arab yang patrilinial -golongan laki-laki masih dominan dari perempuandianggap berbeda dengan paham matrilineal atau parental (bilateral) yang juga dikenal dalam struktur kekeluargaan di Indonesia.

Menurut prinsip kewarisan bilateral sebagaimana yang berlaku dalam hukum kewarisan Islam yang diatur dalam surat anNisa ayat (7) bahwa antara laki-laki dan

${ }^{16}$ Abdullah Siddik, op. cit, him. 24.

${ }^{17}$ Ahmad Azhar Basyir, Refleksi atas Persoalan Ke-Islaman, Seputar Filsafat, Hukum Politik dan Ekonomi (Bandung: Mizan, 1994), hılm. 133.

18Sajuti Thalib, Receptio A Contrario Hubungan Hukum Adat dengan Hukum Islam (Jakarta: Bina Aksara, 1985), him. 62. 
perempuan mempunyai hak untuk menerima warisan dari ayah dan ibu, dan kerabatnya. ${ }^{19}$ Sebagai contoh sebut saja A seorang ayah mempunyai tiga anak, sebut $B$ perempuan, $C$ laki-laki, dan $D$ perempuan. A (ayah) meninggal dunia, dan anak perempuannya yang bernama $B$ dan anak laki-lakinya yang bernama $C$ telah meninggal dunia terlebih dahulu sebelum ayahnya (A). B meninggalkan satu anak perempuan sebut saja $E$ dan $C$ juga mempunyai anak laki-laki sebut saja F. Menurut paham hukum kewarisan Ahlussunnah, maka $E$ anaknya $B$ tidak dapat bagian warisan dari $A$ (kakeknya) karenaE sebagai ahli waris dzawil amam yang ditutup oleh $\mathrm{F}$ cucu laki-laki dari anak laki-laki yang berstatus sebagai ashabah. Penyelesaian dari contoh kasus di atas adalah $D$ mendapat bagian sebagai dzafil furudl yang bagiannya $1 / 2$, dan $F$ sebagai ashabah menerima sisa setelah dikurangi $1 / 2$ bagian $D$.

Kalau contoh kasus tersebut ditinjau dari surat an-Nisa ayat (7), maka apa perbedaan antara $E$ dan $F$ yang dalam hal nasab (keturunan darah) sama-sama sebagai cucu dari pewaris (A). Menurut surat an-Nisa ayat (7) antara $E$ dan $F$ sama-sama merupakan kerabat dari A (kakeknya) dan dia berhak mewarisi hartanya. ${ }^{20}$

Contoh kasus tersebut di atas apabila ditelaah dari sudut pandang prinsip kewarisan parental (bilateral) lebih dekat dengan hukum kewarisan paham Syiah meskipun tidak mutlak semuanya. Sehingga bagi sebagian umat Islam yang berpedoman pada garis kekeluargaan bilateral memandang hukum waris Islam madzhab Ahlussunnah tidak adil karena kedudukan $E$ dan $F$ sama-sama cucu, hanya bedanya $E$ dari garis (keturunan) perempuan sedang $F$ dari garis (keturunan) laki-laki. Bagi orang Islam yang berpaham parental (bilateral) melihat penyelesaian contoh kasus tersebut berakibat penolakan terhadap sistem hukum kewarisan Islam yang berpaham pada Ahlussunnah, sehingga dalam menyelesaikan masalah warisan sering tunduk pada hukum adat, atau dalam bahasa yang ekstrim tidak mau berpedoman pada hukum kewarisan Islam.

Pandangan sebagian umat Islam yang menggunakan hukum waris adat mereka mempunyai anggapan bahwa hukum waris Islam tidak adil dalam menyelesaikan contoh kasus di atas. Pilihan tersebut di satu sisi dapat dipahami karena berpedoman pada paham Ahlussunnah di mana keturunan perempuan ditutup oleh laki-laki. Sebagai contoh kasus di atas, keturunan perempuan (dalam pandangan Ahlussunnah disebut dzawil amam yang dia tidak mendapatkan bagaian warisan sepanjang ada dzawil furudl dan ashobah), padahal kalau ibunya masih hidup maka ibunya tentu bersama saudara laki-lakinya (paman dari cucu perempuan tersebut) mendapatkan warisan. Atas pandangan itulah sehingga banyak umat Islam Indonesia yang masih menolak hukum waris Islam.

${ }^{19} \mathrm{Amir}$ Syarifuddin, "Kedudukan Anak Laki-laki dan Perempuan dalam Hukum Kewarisan islam," Ahmad Azhar Basyir, Masalah Anak Laki-laki dan Anak Perempuan dalam Hukum Waris Islam, (Yogyakarta: Perpustakaan FH.UII, 1988), him. 20.

${ }^{20}$ Ahmad Azthar Basyir, op. cit, hlm. 21. 
Waris Pengganti Jalan Keluar untuk Keadilan dalam Kewarisan Islam

Pertentangan hukum kewarisan Islam di Indonesia berkaitan dengan bagian keturunan perempuan dari perempuan sejak 1991 berangsur-angsur meredah, bahkan dapat dikatakan selesai dengan keluarnya Kompilasi Hukum Islam (KHI) yang terdiri dari 3 (tiga) buku, yaitu: Buku I tentang Perkawinan, Buku II tentang Kewarisan, dan Buku III tentang Perwakafan dan Shadaqah, meskipun masih ada yang belum dapat menerima persoalan hukum kewarisan sebagai produk hukum.

Prinsip hukum kewarisan yang diatur dalam KHI merupakan jalan tengah yang memadukan antara paham Ahlussunnah dengan paham bilateral yang luas tidak hanya terbatas pada keturunan laki-laki saja. ${ }^{21} \mathrm{KHI}$ dianggap sebagai terobosan hukum untuk menyelesaikan persoalan kewarisan yang dipandang adil.

Ketentuan tersebut diatur dalam Pasal 174 , yaitu baik laki-laki dan perempuan mempunyai hak yang sama untuk mewarisi. Prinsip bilateral ini didukung dengan ketentuan Pasal 185 adanya waris pengganti. Prinsip penggantian ini berarti tidak menutup golongan waris perempuan untuk mendapatkan warisan dari si pewaris. Sebagai contoh, ada pewaris sebut saja $A$ seorang ayah mempunyai tiga anak, sebut $B$ perempuan, $C$ laki-laki, dan $D$ perempuan. $A($ ayah) meninggal dunia, dan anak perempuannya yang bemama $B$ meninggal dunia terlebih dahulu sebelum ayahnya $(A)$ dan $B$ meninggalkan satu anak perempuan sebut saja $E$, maka penyelesaiannya $E$ (cucu perempuan dari anak perempuan) tidak tertutup oleh anak laki-laki, tetapi E (cucu perempuan) tersebut menggantikan kedudukan ibu (B yang meninggal dunia terlebih dahulu sebelum pewaris/kakeknya meninggal dunia) yang mewarisi berbagi dengan paman dan bibinya (saudara laki-laki dan perempuan ibunya). Oleh karena $E$ (cucu perempuan) menggantikan ibunya maka bagiannya sama dengan bagian ibunya (B) dan bagian bibinya (D), karena $E$ menggantikan kedudukan ibunya yang sederajat dengan bibinya (D).

Prinsip pemberian waris pengganti dalam KHI sebuah solusi penyelesaian persoalan hukum kewarisan Islam di Indonesia dengan cara berijtihad untuk menemukan hukum kewarisan khususnya bagi keturunan perempuan dari perempuan sebagaimana ketentuan dalam surat an-Nisa ayat (7). Dengan demikian tidak ada alasan lagi bagi umat Islam untuk tidak memilih (menggunakan) hukum waris İlam sebagai dasar penyelesaian persoalan warisan.

\section{Simpulan}

Hukum kewarisan Islam tidak dapat dipisahkan dengan hukum adat. Sebab sistem kewarisan berkaitan dengan garis keturunan seseorang yang dalam proses mewarisi ditentukan oleh dua hal: adanya hubungan perkawinan dan darah atau nasab.

Hukum kewarisan Islam yang masih dipengaruhi Adat kekerabatan parental (kedudukan laki-laki lebih kuat dibanding

\footnotetext{
${ }^{21}$ Hazairin, op cit, hlm. 11-18.
} 
perempuan) dianggap belum mencerminkan keadilan -apabila dikaitkan dengan asas bilateral sebagaimana surat an-Nisa ayat (7), sehingga masih dimungkinkan adanya ijtihad sebagai jalan untuk menemukan hukum yang adil sebagaimana asasnya. Terhadap persoalan ini, Indonesia mengeluarkan ijtihad, materiainya dituangkan dalam Kompilasi Hukum Islam (KHI).

Waris pengganti sebagaimana diatur dalam $\mathrm{KHI}$ merupakan pengembangan dari penafsiran ayat-ayat kewarisan Islam yang lebih luas dan sekaligus sebagai jalan keluar menyelesaikan pertentangan hukum kewarisan Islam selama ini yang merupakan bagian hukum waris Islam di Indonesia.

\section{Daftar Pustaka}

Ali, Muhammad Daud \& Habibah Daud. Lembaga-lembaga Islam di Indonesia. Jakarta: Raja Grafika Persada, 1995

Ash-Shabuni, Muhammad Ali. Pembagian Waris Menunt islam. Alih bahasa A. M. Basalamah. Jakarta: Gema Insani Press, 1995.

Basyir, Ahmad Azhar. Masalah Kedudukan Anak Laki-laki dan Anak Perempuan dalam Hukum Kewarisan Islam. Yogyakarta: Percetakan FH-UII, 1988. Hukum Waris Islam. Yogyakarta: FEUII, 1990.

- Refleksi atas Persoalan Kelslaman Seputar Filsafat, Hukum, Politik dan Ekonomi. Bandung: Mizan, 1994.
Djakfar, Idris dan Taufik Yahya. Kompilasi Hukum Kewarisan Islam. Jakarta: Pustaka Jaya, 1995.

Hazairin. Hukum Kewarisan Bilateral Menurut al-Qur'an dan Hadith. Jakarta: Tintamas, 1982.

Direktorat Pembinaan Badan Peradilan Agama Dirjen Pembinaan Kelembagaan Agama Isiam. Kompilasi Hukum Islam di Indonesia. Jakarta: Direktorat Pembinaan Badan Peradilan Agama Dijen Pembinaan Kelembagaan Agama Islam Departemen Agama Rl, 2000.

Salman, Otje. Kesadaran Hukum Masyarakat terhadap Hukum Waris. Bandung: Alumni, 1993.

Siddik, Abdullah. Hukum Waris Islam dan Perkembangannya di Seluruh Dunia Islam. Jakarta: Wijaya, 1984.

Sukardja, Ahmad.Piagam Madinah dan Undang-Undang Dasar 1945: Kajian Perbandingan tentang Dasar Hidup Bersama dalam Masyarakat yang Majemuk. Jakarta: UI Press, 1995.

Thalib, Sayuti. Hukum Waris Islam di Indonesia. Jakarta: Bina Aksara, 1987. Receptio A Contrario. Jakarta: Bina Aksara, 1995.

Jumal Hukum No. 17 Vol. 8 (2001). 